E International

\title{
Influencing Air Connectivity Outcomes
}

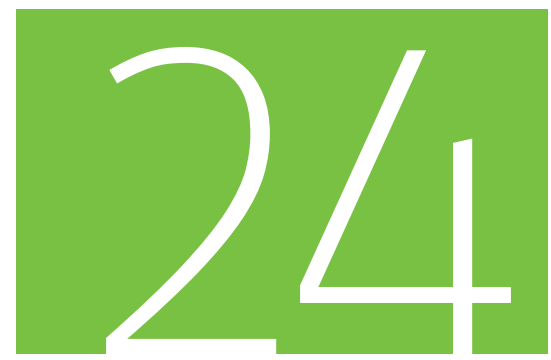

Discussion Paper 2017 • 24

Guillaume Burghouwt

SEO Amsterdam Economics, Amsterdam 


\title{
EInternational \\ Transport Forum
}

\section{Influencing Air Connectivity Outcomes}

\author{
Discussion Paper No. 2017-24
}

Prepared for the Roundtable on

Capacity building through efficient use of existing airport infrastructure

9-10 March 2017, Querétaro

\section{Guillaume Burghouwt}

SEO Amsterdam Economics, Amsterdam, The Netherlands

September 2017 


\title{
The International Transport Forum
}

The International Transport Forum is an intergovernmental organisation with 59 member countries. It acts as a think tank for transport policy and organises the Annual Summit of transport ministers. ITF is the only global body that covers all transport modes. The ITF is politically autonomous and administratively integrated with the OECD.

The ITF works for transport policies that improve peoples' lives. Our mission is to foster a deeper understanding of the role of transport in economic growth, environmental sustainability and social inclusion and to raise the public profile of transport policy.

The ITF organises global dialogue for better transport. We act as a platform for discussion and pre-negotiation of policy issues across all transport modes. We analyse trends, share knowledge and promote exchange among transport decision-makers and civil society. The ITF's Annual Summit is the world's largest gathering of transport ministers and the leading global platform for dialogue on transport policy.

The Members of the Forum are: Albania, Armenia, Argentina, Australia, Austria, Azerbaijan, Belarus, Belgium, Bosnia and Herzegovina, Bulgaria, Canada, Chile, China (People's Republic of), Croatia, Czech Republic, Denmark, Estonia, Finland, France, Former Yugoslav Republic of Macedonia, Georgia, Germany, Greece, Hungary, Iceland, India, Ireland, Israel, Italy, Japan, Kazakhstan, Korea, Latvia, Liechtenstein, Lithuania, Luxembourg, Malta, Mexico, Republic of Moldova, Montenegro, Morocco, the Netherlands, New Zealand, Norway, Poland, Portugal, Romania, Russian Federation, Serbia, Slovak Republic, Slovenia, Spain, Sweden, Switzerland, Turkey, Ukraine, the United Arab Emirates, the United Kingdom and the United States.

\author{
International Transport Forum \\ 2 rue André Pascal \\ F-75775 Paris Cedex 16 \\ contact@itf-oecd.org \\ WWW.itf-oecd.org
}

\section{ITF Discussion Papers}

ITF Discussion Papers make economic research, commissioned or carried out in-house at ITF, available to researchers and practitioners. They describe preliminary results or research in progress by the author(s) and are published to stimulate discussion on a broad range of issues on which the ITF works. Any findings, interpretations and conclusions expressed herein are those of the authors and do not necessarily reflect the views of the International Transport Forum or the OECD. Neither the OECD, ITF nor the authors guarantee the accuracy of any data or other information contained in this publication and accept no responsibility whatsoever for any consequence of their use. This document and any map included herein are without prejudice to the status of or sovereignty over any territory, to the delimitation of international frontiers and boundaries and to the name of any territory, city or area. Comments on Discussion Papers are welcome. 


\begin{abstract}
The aviation network plays an important role in today's globalised society. There is a growing understanding among governments worldwide that air connectivity is an asset improving the global competitiveness of cities, regions and countries. Connectivity growth decreases travel costs for consumers and businesses and facilitates global contacts and trade. There is increasing evidence that air connectivity growth stimulates productivity, $R \& D$, foreign direct investment and fosters trade specialisation.

Against this background, many governments try to formulate (aviation) policies to influence/ enhance connectivity outcomes, so as to achieve a connectivity portfolio that best meets society's needs. This seems to be particularly an issue when airport capacity is scarce or when new airports are added to an existing airport system. Hence, the ITF posed the question how governments can influence connectivity outcomes.

To answer this question, we first discuss the concept of air connectivity, the economic value of connectivity and its determinants. We then identify the instruments that can potentially be part of the government's "toolkit" to influence connectivity outcomes. Finally, we discuss two approaches that governments may follow when influencing connectivity outcomes: a market-based approach and an interventionist, administrative approach. We discuss the pros and cons of both approaches and argue that governments should be modest about steering connectivity outcomes using an administrative approach.

This paper is focused on the European context in terms of the specific policy instruments that are discussed. However, the insights derived from this paper are likely to apply for other regions as well.
\end{abstract}




\section{Table of contents}

The concept of air connectivity ........................................................................................................5

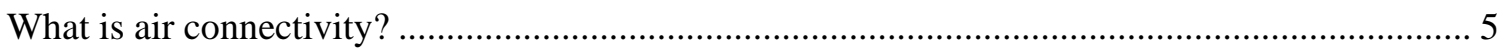

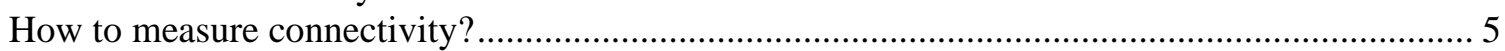

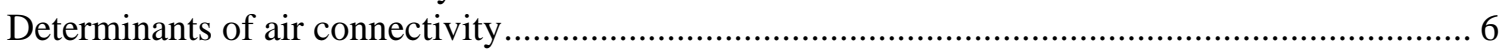

Why governments care about connectivity ............................................................................................ 10

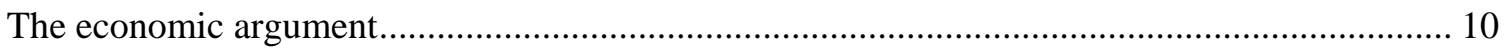

The toolkit at hand: Which options can governments use to influence

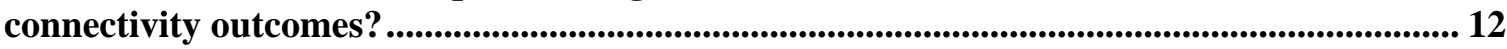

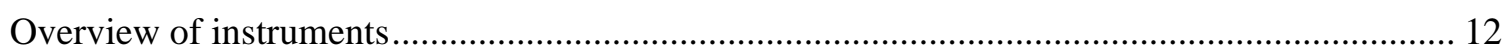

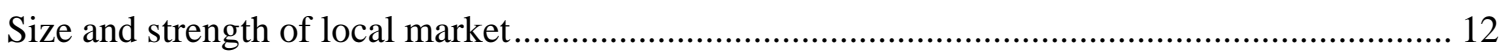

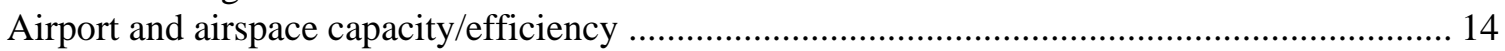

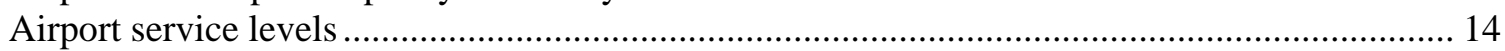

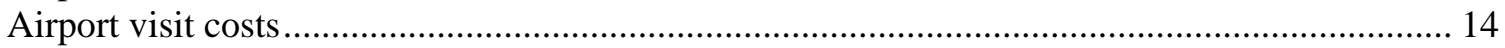

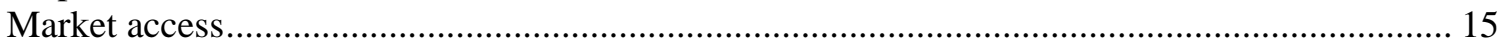

An administrative or market-based approach? ..................................................................................... 19

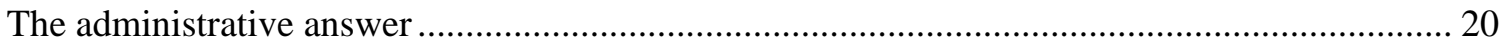

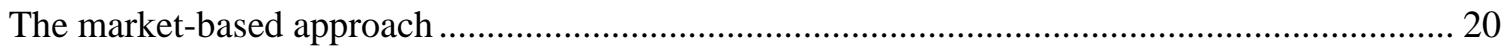

Intervening to promote connectivity or let the market do its work? ............................................ 22

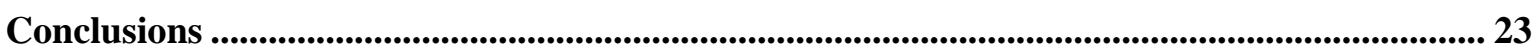

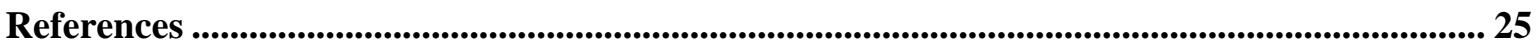

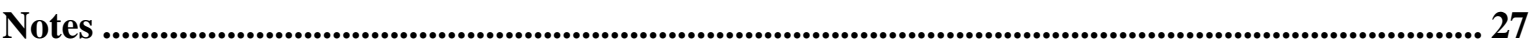

\section{Figures}

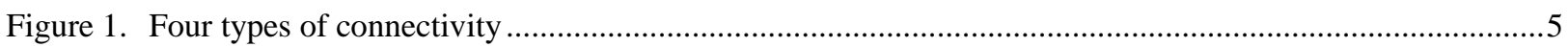

Figure 2. Direct and indirect connectivity per week for the 14 best-connected airports in Latin America.................6

Figure 3. Car travel time catchment areas for 20 European airports..................................................................

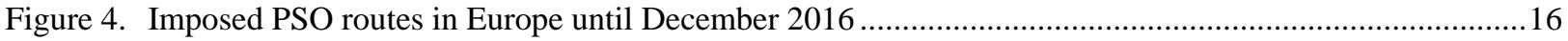

\section{Tables}

Table 1. Overview of airport visit costs .9

Table 2. Instruments to influence aviation connectivity outcomes....................................................................13 


\section{The concept of air connectivity}

\section{What is air connectivity?}

Connectivity is generally defined as: "degree to nodes in a network are connected to each other" (Burghouwt and Redondi 2013, p.37). Generally, a distinction is made between direct connectivity (direct flights), indirect connectivity (connections involving a transfer at an intermediate hub) and hub connectivity (the number of connection opportunities via a certain hub airport) (Figure 1).

While direct and indirect connectivity relate to the connectivity available to local passengers, hub connectivity is an indication of the competitive strength of an airport in the connecting market. All other things being equal (e.g. price, in-flight service quality), passengers will generally prefer direct, non-stop connections over indirect, over-the-hub connections due to the additional transfer and detour time involved. However, indirect connections also count for a country's connectivity portfolio: they provide a competitive constraint for the direct connections on offer and they provide access to the many destinations with too little demand for a direct flight.

\section{Figure 1. Four types of connectivity}

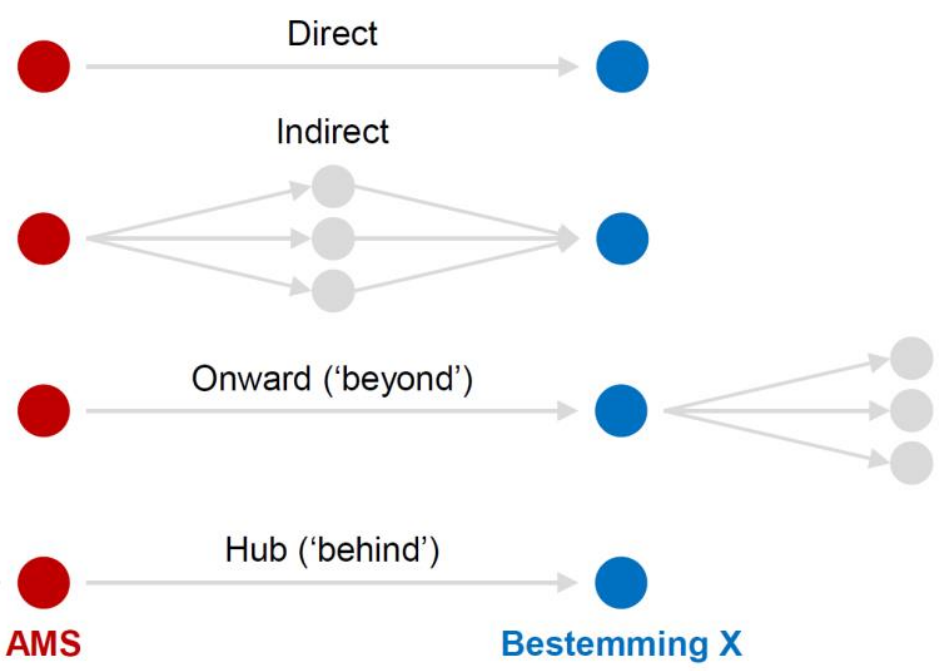

\section{How to measure connectivity?}

A large body of literature has emerged on the measurement of air connectivity. Many models are available to benchmark the connectivity performance of airports, countries and regions and to compare connectivity developments over time. Generally, they count the number of direct and indirect connections available at an airport, taking into account criteria such as minimum connecting time, maximum detour factor and a definition of what constitutes an "online" connection. Since direct and indirect connections differ in quality due to in-flight time differences, the inconvenience and risk of missing a connection and transfer time, some models attach a weight to each connection depending on 
the quality of the connection relative to a direct flight. We refer to Burghouwt and Redondi (2013) for a review of connectivity models and guidelines on which type of connectivity model to use in which circumstances.

Connectivity models have demonstrated their usefulness in benchmarking a region's or airport's air connectivity. Applications of connectivity models include the annual connectivity benchmark of Amsterdam Airport in comparison to competing hub airports (Van Spijker et al., 2017) and the European airport industry connectivity report (ACI EUROPE, 2016). Figure 2 illustrates the application of a connectivity model to the largest airports in Latin America for 2014.

\section{Figure 2. Direct and indirect connectivity per week for the 14 best-connected airports in Latin America}

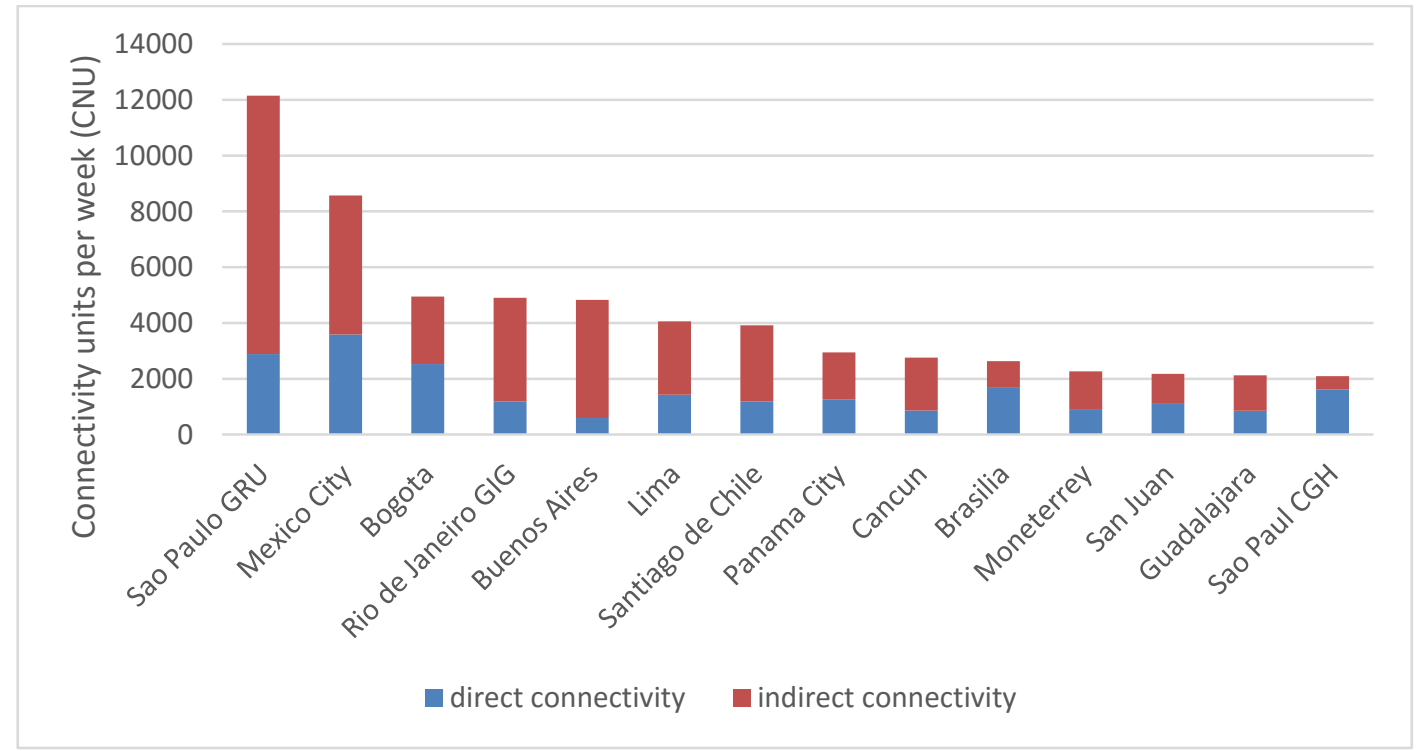

Note: CNU is the number of direct and indirect connections per week, corrected for the quality of each individual connection in terms of detour and transfer time relative to a theoretical direct flight.

Source: SEO NetScan; OAG data for 2014.

However, connectivity models are focused on counting the supply of routes and frequencies. They do not take into account the value different passenger segments (business/leisure passengers) attach to travel time (in-flight, transfer time, schedule delay) and omit ticket price as an important passenger itinerary choice variable. As such, connectivity models are less useful to explain observed passenger choice behaviour or to estimate direct user (welfare) benefits of connectivity improvements. Generalised travel cost models are much better able to do so, as such models try to capture all time and monetary costs that travellers face for the various travel options between initial origin and final destination, taking into account travellers' values of time (Lieshout et al., 2012; Mandel et al., 2017).

\section{Determinants of air connectivity}

Various factors determine the air connectivity performance of an airport or region.

\section{Size and strength of local origin-destination market}

One of the most important factors for the connectivity of airports is the size and strength of the local origin-destination (OD) market. With respect to passenger traffic, the size and economic strength of the local catchment area drives outbound demand. Size and economic activities as well as tourism 
attractiveness are an important variable in explaining inbound demand (including the "propensity to fly"). Here, landside accessibility drives the size of the catchment area that airlines can serve from a particular airport within a certain landside travel time (Figure 3). Apart from the socio-economic variables, also cultural, political and historical ties play a role in explaining demand at the origin-destination level. The research on the factors that explain air travel demand at the origindestination or airport level is widespread, including gravity modelling (e.g. Abed et al., 2001; Bahdra, 2003; Grosche et al., 2007) and regressions on aggregate airport demand (Dobruszkes, 2011).

Figure 3. Car travel time catchment areas for 20 European airports

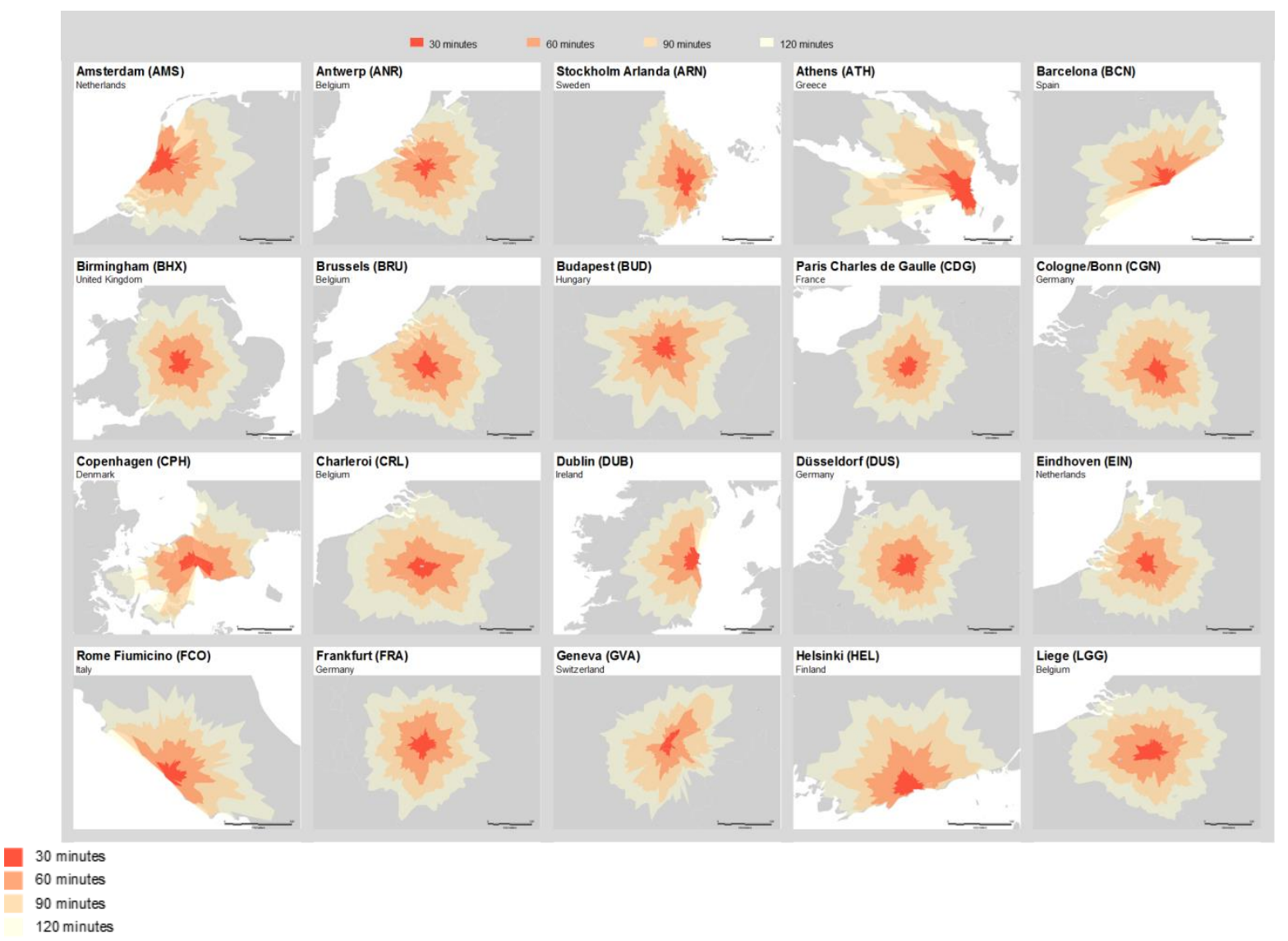

Source: SEO Airport Catchment Area Database.

Competition from other airports serving the same market can distort the relationship between local market and connectivity. An airport that is the only one serving certain metropolitan area will be more advantageous in terms of connectivity growth than multiple airports (partly) serving the same market, assuming sufficient availability of capacity.

The relationship between the size and strength of the local market and air connectivity is bi-directional. Air travel contributes to the efficient functioning of the economy in the airport region. Economic growth may again stimulate the demand for air travel and connectivity.

\section{Presence of an airline hub operation}

Hub airports benefit from a connectivity premium. Paraphrasing former Northwest executive Mike Levine (2009), the game in the airline industry is to generate sufficient traffic (passenger) density on a 
flight at a price that covers the cost. This works best in large origin-destination markets where there is sufficient demand to operate routes profitably. However, the majority of the world's origin-destination markets has insufficient local demand for a direct flight.

One answer of airlines to the route density problem is to operate a hub-and-spoke network and fill "the empty seats" with transfer traffic. In Levine's words, "network airlines are nothing more or less than factories to manufacture route density". By combining local traffic to and from the hub with transfer traffic, the hub carrier can operate many more destinations directly than would be possible without the hub operation.

Airports that facilitate a large airline hub operation benefit from a connectivity premium: the number of long-haul destinations is larger than one would expect based on local demand alone. When an airport loses its hub function (e.g. bankruptcy of the home carrier, rationalisation), the number of longhaul connections generally drops substantially, as the decrease in transfer passenger volumes make many long-haul destinations unprofitable. Lieshout et al. (2016) estimate a $26 \%$ reduction in long-haul destinations and a 38\% decrease in long-haul frequencies if Amsterdam Airport would lose the hub operation by KLM and partners.

Due to the economies of scope and density associated with hub operations as well as the specific requirements for airport infrastructure, relatively few airports facilitate large airline hub operations. Necessary but not sufficient conditions for airports to develop as a hub are:

- a central geographical location in relation to global or continental traffic flows

- a large and strong catchment area (including good landside accessibility)

- $\quad$ high peak-hour capacity

- $\quad$ short minimum connecting times

- a high airport service level/quality/ airport amenities

- competitive visit costs

- large portfolio of traffic rights for the hub carrier (in case of international hubs)

- year-round reliability of peak-hour capacity.

The development of hubs over time is characterised by path dependency. There are cost, demand and connectivity advantages for a carrier to add flights from an already established hub. Each new flight that the hub carrier adds to the hub generates a multitude of connecting opportunities via the hub. The other way around, once an airport loses its hub function (dehubbing), it is not easily regained (Redondi et al., 2012).

\section{Airport and airspace capacity}

Sufficient (peak-hour) airport capacity is an essential condition for connectivity growth. The same holds true for airspace/ATC capacity. As many airports are located in densely populated areas and capacity expansion may require substantial investments, airport expansion throughout the world has proven not be easy. According to Eurocontrol (2013), in $203512 \%$ of the forecasted flights cannot be accommodated at Europe's airports due to airport capacity shortages. 


\section{Airport visit costs}

Airlines take into account airport visit costs in their route development strategy. Visit costs may also influence passenger choice behaviour when airlines pass on higher/lower charges to the passenger through air fares. Although airport visit costs generally represent a limited share of an airline's total operational costs, this share can be more significant for short haul flights as well as for low fare airlines. Typical examples of airlines with high shares of visit costs are Ryanair and EasyJet. Table 1 summarises the various airport visit costs.

\section{Table 1. Overview of airport visit costs}

\begin{tabular}{|c|c|c|c|c|}
\hline $\begin{array}{l}\text { Airport charges } \\
\text { and passenger } \\
\text { fees }\end{array}$ & $\begin{array}{l}\text { Government } \\
\text { taxes }\end{array}$ & ATC charges & $\begin{array}{l}\text { Costs for } \\
\text { airside third } \\
\text { party service } \\
\text { providers }\end{array}$ & Other \\
\hline Landing charge & Noise tax & $\begin{array}{l}\text { Terminal } \\
\text { navigation } \\
\text { charge }\end{array}$ & Fuel costs & $\begin{array}{l}\text { Costs for } \\
\text { renting lounge } \\
\text { space }\end{array}$ \\
\hline $\begin{array}{l}\text { Parking charge } \\
\text { for aircraft }\end{array}$ & Security tax & & $\begin{array}{l}\text { Ground } \\
\text { handling fees }\end{array}$ & $\begin{array}{l}\text { Costs for } \\
\text { renting on- } \\
\text { airport office } \\
\text { space }\end{array}$ \\
\hline Passenger charge & $\begin{array}{l}\text { Air passenger } \\
\text { tax }\end{array}$ & & Catering costs & $\begin{array}{l}\text { Costs for } \\
\text { renting on- } \\
\text { airport crew } \\
\text { facilities (in } \\
\text { case of base } \\
\text { operation) }\end{array}$ \\
\hline Security charge & Other taxes & & $\begin{array}{l}\text { Third party } \\
\text { maintenance } \\
\text { costs }\end{array}$ & $\begin{array}{l}\text { Overnight } \\
\text { accommodation } \\
\text { costs }\end{array}$ \\
\hline $\begin{array}{l}\text { Boarding bridge } \\
\text { charge }\end{array}$ & & & & $\begin{array}{l}\text { Costs for } \\
\text { renting of on- } \\
\text { airport } \\
\text { customer } \\
\text { service/ticket } \\
\text { sales facilities } \\
\end{array}$ \\
\hline \multicolumn{5}{|l|}{$\begin{array}{l}\text { Development } \\
\text { charge }\end{array}$} \\
\hline \multicolumn{5}{|l|}{ Check-in charge } \\
\hline \multicolumn{5}{|l|}{ Terminal charge } \\
\hline \multicolumn{5}{|l|}{ Cargo charge } \\
\hline Noise charges & & & & \\
\hline $\begin{array}{l}\text { Emission } \\
\text { charges }\end{array}$ & & & & \\
\hline
\end{tabular}

Source: SEO.

\section{Airport service levels}

For keeping and attracting passengers, airlines and airports compete with services that improve the passenger experience. Such service factors concern for example walking distances and waiting times for security, immigration and luggage, but also relate to the layout of terminals, shopping facilities, 
atmosphere and space, cleanliness, friendliness of staff and availability of dedicated lounges. Together they determine the image of an airport and its perceived value by passengers and airlines.

\section{Market access}

Airlines can only offer connectivity in those markets where they have access to. Availability of traffic rights (via bilateral air service agreements or open skies treaties), the slot allocation regime, regulatory restrictions on airport use by airlines (e.g. traffic distribution rules or local rules in the slot allocation) and infrastructure restrictions (e.g. runway length or gate positions) are variables that determine/influence market access levels.

\section{Why governments care about connectivity}

Many governments formulate (aviation) policies to influence/enhance air connectivity outcomes. The arguments for government to do so are diverse. Without going into their economic validity (i.e. is there an economic rationale for government intervention?), we observe in practice the following arguments.

\section{The economic argument}

In today's globalised society, international accessibility by air is considered to be a key asset for the competitiveness of cities, regions and countries.

\section{Direct user benefits}

Connectivity improvements generate direct user (welfare) benefits as they bring down travel costs for consumers, both in terms of time costs and monetary costs. For example, a new direct route from Querétaro to Los Angeles will reduce travel costs for local Mexican consumers. Users directly benefit from a reduction in travel time as they are longer bound to a time-consuming transfer at an intermediate hub airport. Similarly, when Aeroméxico were to increases the frequency on the Mexico-Amsterdam route, consumers would then benefit from more choice, in the sense that it becomes more likely that their actual departure/arrival time is close to their desired departure/arrival time.

\section{Wider economic benefits}

The impact of lower travel costs due to better connectivity (direct user benefits) ripples through the rest of the economy. For example, businesses benefit from lower travel costs and they may see profits increase or can pass on the lower costs to their clients. Most of these wider economic benefits are just a pass-through of lower travel costs to actors elsewhere in the economy: they are already captured by measuring direct user benefits.

However, improvements in connectivity may also generate additional benefits in the wider economy in case of market imperfections. Examples of additional wider economic benefits are agglomeration effects. Connectivity growth in an airport region may lead to a higher density of economic activities in that region. Concentration of economic activities in itself can reduce (spatial) market imperfections and result in higher productivity measured in GDP/capita, for example because of knowledge and technology 
spill-overs, a pooled labour market and access to a larger diversity of products/inputs. In addition, a reduction of air transport costs may allow firms to profitably increase output, resulting in falling unit costs and reduced prices for end consumers. Furthermore, increased air connectivity may bring about an increase in international trade, which enhances productivity (Airports Commission, 2015).

\section{Box 1. The economic value of air connectivity}

Many studies have demonstrated a significant statistical relationship between connectivity changes and regional-economic growth. Bel and Fageda (2008) find that a 10\% growth in intercontinental flights from European metropolitan areas results in a $4 \%$ growth in the number of headquarters, all other things being equal. IATA (2007) concludes that a $10 \%$ growth in connectivity relative to GDP results in a $0.07 \%$ increase in GDP per hour worked. According to research by Gillen et al. (2015) connectivity affects multi-factor productivity of industries in the USA, but states that the impact differs across industries. A positive relationship was found between connectivity (new destinations) and the net amount of jobs and business establishments in US metropolitan areas (Bilotkach, 2015). According to Brueckner (2003), a 10\% increase in passenger enplanements leads to a $1 \%$ increase in employment in service related industries in US metropolitan areas. Hovhannisyan and Keller (2014) report that a $10 \%$ increase in business travel results in an increase in patenting by about $0.2 \%$, covering outward business travel from the United States. Baruffaldi (2015) finds that innovative firm productivity increased significantly in those German regions where airline liberalisation induced a higher level of interregional knowledge integration.

To integrate the direct user (welfare) benefits of connectivity improvements in the social cost-benefit analysis (SCBA) or welfare analysis generalised travel cost models are more appropriate to use. They can be used to evaluate for example the direct user benefits of connectivity changes, airport capacity investments and policy interventions. One example of a generalised travel cost model, specifically developed for the aviation market is NetCost (Burghouwt, 2016; Lieshout and Matsumoto, 2012; Lieshout, 2012; Lieshout et al., 2016). The NetCost model identifies available direct and indirect travel options from a certain (set of) originating regions to all possible final destination regions. It estimates the travel costs (in time and money) for all the available travel options and translates them into monetary terms. NetCost translates the change in generalised travel costs in relation to the change in passenger numbers into consumer welfare impacts/direct user benefits in a given scenario, in comparison to a reference situation, including market (de)generation effects. In addition, wider economic benefits of connectivity improvements as well as producer surplus may arise.

\section{Improve air connectivity outcomes given scarce airport capacity}

When airport capacity is constrained, governments may want to ensure that connectivity is on offer that delivers the greatest economic contribution to the country or region. Sometimes, government policy is aimed at stimulating the utilisation of newly created airport capacity and ensuring that connectivity is developed at a certain airport site. The Italian government for example, imposed traffic distribution rules to stimulate the use the newly created capacity at Milan Malpensa instead of the congested airport Milan Linate (see later on in this paper).

\section{Social and political objectives}

Government can have certain social or political goals in terms of connectivity development that do not necessarily reflect economic efficiency. Such goals can relate to improving for example connectivity to domestic airports or ensuring connectivity from peripheral regions into the main economic centres. Public service obligations is a well-known instrument for improving connectivity from peripheral European regions. 


\section{Protect national champions}

Government policy to influence connectivity outcomes can also serve the interests of the national/incumbent carriers, implicitly or explicitly. The initially formulated traffic distribution rules for the Milan airport system for example ensured de facto unique access by Alitalia to the high yielding traffic at Milan Linate. More subtle are the charge differentiations between OD and transfer passengers at many hub airports around the world (Zuidberg, 2014). Although lower charges for transfer passengers may reflect more limited infrastructure requirements in certain cases and may be necessary to maintain market share in a highly elastic transfer market, differentiation may also favour the home-based carrier.

\section{Reduction of environmental externalities}

Governments may want to achieve a connectivity portfolio that minimises the environmental burden. Examples of instruments used include differentiation of airport charges according to noise emissions, noise levies or a ban on the noisiest aircraft.

\section{The toolkit at hand: Which options can governments use to influence connectivity outcomes?}

\section{Overview of instruments}

After the review of variables that determine connectivity outcomes, the question is which options governments have to influence connectivity outcomes. Table 2 lists the potential instruments available to different stakeholders. The list refers to the European context. The possibilities for using the instruments may be different for other jurisdictions. In addition, we assume that airports are not directly under government ownership and/or operate independently from government. In case of governments owning/operating the airports, governments may have more possibilities to influence connectivity outcomes directly.

\section{Size and strength of local market}

Investments by governments in airport accessibility can extend the airport's catchment area when they reduce the access and egress costs. They include improvements in the road, rail and bus networks. A broader demand base will increase opportunities for airlines to grow their network and enhance the airport's connectivity. We note that infrastructure investments can also result in additional catchment area leakage: infrastructure improvements in one airport region may also lead to better access to other, competing airports. In addition, liberalisation will allow (low-cost) carriers to enter the market. More competition and lower fares can stimulate demand and extend the airport's catchment area. 
Table 2. Instruments to influence aviation connectivity outcomes

\begin{tabular}{|c|c|c|c|}
\hline $\begin{array}{l}\text { Determinants of } \\
\text { airport connectivity }\end{array}$ & Possible instruments & $\begin{array}{l}\text { Within policy } \\
\text { makers' reach? }\end{array}$ & Main stakeholder(s) \\
\hline \multirow[t]{4}{*}{$\begin{array}{l}\text { Size and strength of } \\
\text { local market }\end{array}$} & $\begin{array}{l}\text { Investment in landside accessibility to } \\
\text { decrease airport access times }\end{array}$ & Yes & Government \\
\hline & $\begin{array}{l}\text { Launch marketing campaigns to increase } \\
\text { awareness of airport in the catchment area } \\
\text { or awareness of city as destination for } \\
\text { tourism/business }\end{array}$ & No & $\begin{array}{l}\text { Airport, tourism } \\
\text { association, Chambers of } \\
\text { Commerce }\end{array}$ \\
\hline & $\begin{array}{l}\text { Remove barriers to entry for (low-cost) } \\
\text { carriers through liberalisation/additional } \\
\text { traffic rights }\end{array}$ & Yes & Government \\
\hline & $\begin{array}{l}\text { Soften visa requirements to stimulate } \\
\text { inbound travel }\end{array}$ & Yes & Government \\
\hline \multirow[t]{4}{*}{$\begin{array}{l}\text { Airport service level } \\
\text { and quality }\end{array}$} & Investment in airport amenities & $\begin{array}{l}\text { No (unless airport } \\
\text { service levels are } \\
\text { part of regulatory } \\
\text { framework) }\end{array}$ & $\begin{array}{l}\text { Airport, airlines, third party } \\
\text { service providers }\end{array}$ \\
\hline & Ensure efficient terminal lay-out & No & Airport \\
\hline & $\begin{array}{l}\text { Ensure efficient border control + customs } \\
\text { process }\end{array}$ & Yes & Government \\
\hline & Ensure efficient gate allocations & No & Airport \\
\hline Airport capacity & $\begin{array}{l}\text { Create (timely) availability of sufficient } \\
\text { airport capacity to accommodate traffic } \\
\text { growth through planning permissions, } \\
\text { noise quota etc. }\end{array}$ & Yes & $\begin{array}{l}\text { Government, airport, local } \\
\text { communities and authorities }\end{array}$ \\
\hline Airspace efficiency & $\begin{array}{l}\text { Ensure integration and more efficient } \\
\text { layout of airspace }\end{array}$ & Yes & $\begin{array}{l}\text { Government, Air } \\
\text { Navigation Service } \\
\text { Providers } \\
\end{array}$ \\
\hline \multirow[t]{5}{*}{ Airport visit costs } & $\begin{array}{l}\text { Ensure competitive airport charges and } \\
\text { fees }\end{array}$ & $\begin{array}{l}\text { Yes, in case of } \\
\text { economic } \\
\text { regulation of airport }\end{array}$ & $\begin{array}{l}\text { Government/ regulator, } \\
\text { airport }\end{array}$ \\
\hline & $\begin{array}{l}\text { Change government taxes (noise tax, air } \\
\text { travel tax, security tax) }\end{array}$ & Yes & Government \\
\hline & Set ATC charges & $\begin{array}{l}\text { Yes, through } \\
\text { regulatory } \\
\text { framework }\end{array}$ & ATC provider, government \\
\hline & $\begin{array}{l}\text { Reduce airline costs by third party } \\
\text { providers }\end{array}$ & No & $\begin{array}{l}\text { Third party providers (but } \\
\text { governments/airports may } \\
\text { liberalise certain } \\
\text { downstream markets such } \\
\text { as ground handling) }\end{array}$ \\
\hline & $\begin{array}{l}\text { Offer start-up aid, airline incentive } \\
\text { programmes }\end{array}$ & Yes & $\begin{array}{l}\text { Airport, government, local } \\
\text { authorities }\end{array}$ \\
\hline \multirow[t]{5}{*}{ Market access } & Impose public service obligations & Yes & Government \\
\hline & Impose traffic distribution rules & Yes & Government \\
\hline & $\begin{array}{l}\text { Negotiate traffic rights through bilateral } \\
\text { air service agreements; Negotiate open } \\
\text { skies treaties }\end{array}$ & Yes & Government \\
\hline & Adjust slot allocation regime & Yes & $\begin{array}{l}\text { Government, slot } \\
\text { coordinator }\end{array}$ \\
\hline & $\begin{array}{l}\text { Infrastructure restrictions that affect } \\
\text { market access (runway length, gate } \\
\text { positions, airport opening hours) }\end{array}$ & Yes & Government, airport \\
\hline
\end{tabular}




\section{Airport and airspace capacity/efficiency}

Timely development of airport capacity is needed if governments want to reap the economic benefits of air connectivity growth. Insufficient capacity in comparison to the underlying demand results in foregone connectivity growth. Careful evaluation of proposed investments in airport infrastructure (social-cost benefit analysis and business cases) is important in this context.

The same reasoning holds true for airspace capacity and efficiency. In particular in Europe, airspace is not efficiently organised, which leads to higher than necessary costs for airlines (including delay costs) and environmental externalities. However, modernisation of European airspace through the Single European Sky programme/SESAR is progressing slowly.

We note that decisions by the government or airport operator on the type of airport infrastructure available will affect connectivity outcomes. Runway length is the most obvious example, which will determine the extent to which an airport can handle long-haul flights. Other examples are the type and number of gate positions or availability of dedicated facilities for certain carriers.

\section{Airport service levels}

The airport service level is generally in the hands of airport operators/airlines. When airport service levels are within the scope of the economic regulation of airports, governments/regulators may exercise a certain influence on them. In addition, at many airports border control and customs (and sometimes airport security) is a direct government responsibility. At hub airports, the efficiency of the border control process is particularly important as it influences the minimum connecting time between flights.

\section{Airport visit costs}

Either by economic regulation or by ensuring that there are sufficient competitive constraints on an airport's pricing behaviour, governments can help to ensure that charges and fees are at reasonable/competitive levels. In addition, governments are likely to have direct influence on certain visit costs, such as air travel taxes (like the UK APD), security fees and noise levies. ${ }^{1}$ Benchmarking can help governments to assess the level of charges, fees and taxes at the airport in question compared to its main competitors.

\section{Incentive programmes and start-up aid}

Airlines are not always prepared to run the risk of opening new routes from unknown and untested airports. The current financial state of the airline industry does not allow airlines to endure heavy losses while they try to develop the new route into profitability. Hence, incentive packages can be an important decision factor for airlines before committing to a new air service. Airports, governments, tourism organisations and chambers of commerce increasingly provide airlines with start-up aid as an incentive to offer flights to specific destinations or regions. They include for example rebates on airport charges, joint marketing support or revenue guarantees. Start-up aid and incentives may need to comply with local regulations on state aid by governments such as the EU "Guidelines on State Aid to Airports and Airlines". 2 


\section{Box 2. Start-up aid under the Regional Air Connectivity Fund}

The Regional Air Connectivity Fund is a UK government initiative for start-up aid to airlines to stimulate connectivity from and to regional airports. It has to meet the conditions of the EU guidelines on state aid. The Fund is intended for PSO routes and for the launch of new routes from regional airports that handle fewer than five million passengers a year. Bids for funding need to come from consortia (route promoters) consisting of at least an airport and an airline and where applicable a local authority. The new routes need to create net economic benefits for the region. New services should be expected to be profitable after three years. Funding can cover up to $50 \%$ of the aeronautical charges. Funding is only available for routes within the Common European Aviation Area. The initiative was launched in 2013 (Burghouwt and De Wit, 2015b, p.15). By the end of 2015, 11 successful bidders had been awarded support from the fund including routes from Newquay and Dundee to Leeds-Bradford and Amsterdam respectively.

\section{Market access}

\section{Public service obligations $^{3}$}

To ensure entry of airlines to certain markets, governments can impose public service obligations (Europe) or Essential Air Service Programmes (USA) ${ }^{4}$. In Europe, governments can establish air services under public service obligations (PSO)in order to maintain scheduled air services on routes considered to be vital for the economic development of the region they serve but unprofitable for any airline to operate under competitive market conditions.

In Europe, procurement of air services under a PSO is governed by EU Regulation 1008/2008 on the common rules for operation of air services in the Community. The general approach is to procure services under a PSO through competitive tendering (art. 17). PSO carriers can either receive financial compensation to cover operational losses or be granted a route monopoly to protect them from price competition for a period of up to four years, after which the situation shall be reviewed. PSO routes in Europe are particularly found in Norway, Sweden, France, the United Kingdom, Spain and Portugal.

\section{Opportunities and potential challenges to consider by governments}

European governments have direct influence on connectivity outcomes, as it can impose PSOs according to EU Regulation 1008/2008. National governments have quite some discretionary power when imposing PSOs. Although EU Member States have to communicate the text of an envisaged PSO to the European Commission, no approval by the European Commission is needed. Furthermore, PSOs are fully compatible with the slot allocation regime in the sense that slots may be reserved for PSO routes at congested airports, assuming there are available slots in the pool.

On the other hand, European PSOs can only be implemented on routes between Community airports and airports within the territory of a Member State. This means they are in general not suitable for longhaul routes to outside of the EU. PSOs may undermine the most efficient use of airport capacity from an economic point of view. The use of scarce airport slots by PSO routes does not necessarily represent the optimal use of scarce airport capacity, i.e. it undermines use by the airlines that attach the highest value to those slots. 
Figure 4. Imposed PSO routes in Europe until December 2016

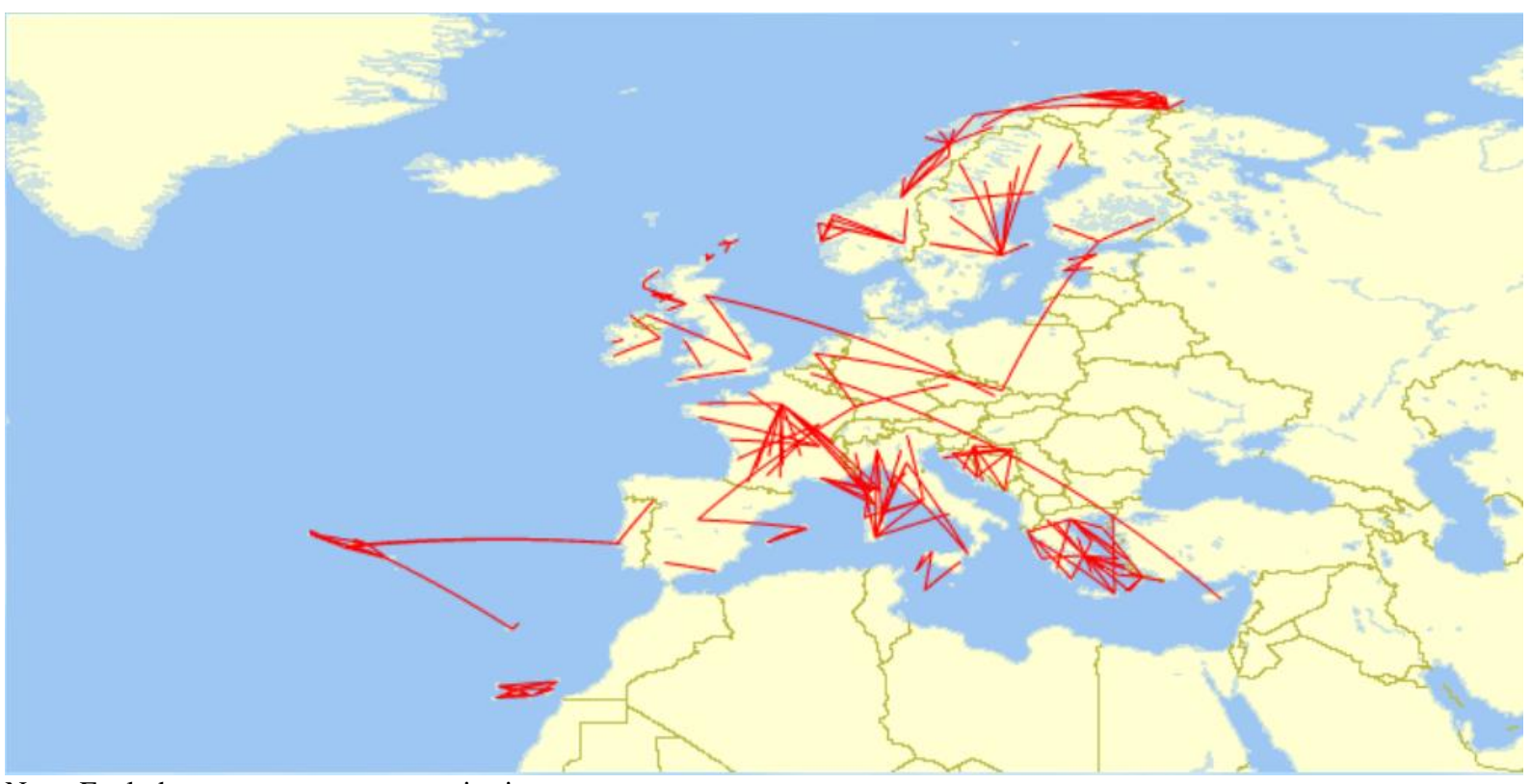

Note: Excludes routes to overseas territories.

Source: European Commission (https://ec.europa.eu/transport/modes/air/internal-market/public-service-obligations-psos en).

\section{Box 3. Criteria for introducing PSOs in Europe}

Criteria for introducing PSO routes have been relatively loosely defined in the European law. Article 16 of Regulation 1008/2008 states that a member state may impose a PSO with respect to scheduled air services between an airport in the community and an airport:

- $\quad$ serving a peripheral region in its territory;

- $\quad$ serving a development region in its territory or a thin route to any airport on its territory, when the route is being considered vital for economic and social development of the region which the airport serves.

The member state shall only use the PSO to ensure a minimum provision of scheduled air services, which no air carrier would operate if they were solely considering commercial interests. When a member state wishes to impose a PSO, it must communicate the text of the envisaged PSO to the European Commission, other member states concerned, the airports concerned and to the air carriers operating the route in question. Furthermore, in evaluating the necessity and adequacy of the PSO, EU Regulation 1008/2008 requires that the member state should take into account:

- the proportionality between the PSO and economic development of the region concerned

- $\quad$ alternative modes of transport, in particular when existing rail services serve the envisaged PSO route with a travel time of less than three hours.

\section{Traffic distribution rules ${ }^{5}$}

Government rules aimed at regulating the traffic distribution between different airports serving the same conurbation are known in Europe as traffic distribution rules (TDRs), governed by article 19 of EU Regulation 1008/2008. But equivalent government policies are/have been used in Japan (Haneda vs. Narita), Korea (Incheon vs. Gimpo) and the USA (the "perimeter rule" at LaGuardia). Such government policies can substantially affect the connectivity at the airports concerned. 
Most TDRs are imposed to ensure that certain types of traffic do not use an airport to reduce congestion, to address environmental concerns (e.g. noise nuisance at a city airport) or to stimulate carriers to use other airports serving the same conurbation. In case of Milan, TDRs were implemented by the Italian government in order to force carriers to move their operations from Milan Linate to Milan Malpensa. TDRs in London are in place to exclude full-freighter traffic, general aviation and business aviation from using Heathrow and Gatwick at peak hours. ${ }^{6}$

\section{Box 4. Traffic distribution rules for Milan}

In 2000, when the new terminal in Malpensa opened, the Bersani Decree introduced TDRs for the airports serving Milan. The objective of the TDRs was to steer traffic away from Linate and turn Malpensa into an international hub (Redondi, 2013). For each community carrier, the TDR limits the frequency of scheduled services from Milan Linate to European airport systems or individual airports according to size of the destination. The European Commission allowed the Italian government to apply the TDRs as laid down in the Decree. We refer to the exact specification of the Milan TDR to Redondi (2013, pp. 494-495).

To meet the TDR conditions, the Italian and regional governments made large investments to improve access to Malpensa by surface transport and extend its catchment area. A train connection, the Malpensa Express, was introduced to connect the airport to the Milan central station. Several improvements to the highway system were undertaken in the local area.

The Milan TDRs did not achieve their objective of turning Malpensa in an international hub. According to Redondi (2013), allowing Linate to continue to operate to the main Italian and European destinations (instead of closing the airport) contributed to the de-hubbing of Milan Malpensa by Alitalia: business passengers for larger European destinations disliked the long access times to Malpensa and preferred nearby Linate, cannibalising demand and yields for feeder flights to Malpensa. For long-haul destinations, passengers preferred transferring at other major European airports over a direct flight (with a longer access time) from Malpensa. The limited market potential of Malpensa and restrictions at Linate forced airlines to search for new market opportunities: as such, the TDRs stimulated the growth of low-cost airport Bergamo-al-Serio, located 40 kilometres east of Milan.

Furthermore, the TDRs incentivised airlines to search for loopholes in the TDRs (Redondi, 2013). By employing multiple carrier code assignments, several airlines were able to increase their frequencies from Linate and circumvent the TDRs. For example, Alitalia increased its flight frequency to London Heathrow and Paris Charles de Gaulle by using the assignments given to subsidiaries and carriers it had previously acquired: Air One, Volare Airlines, and Alitalia Express. Lufthansa, by using its subsidiary Air Dolomiti, increased its frequency to Frankfurt above its formal limit of two daily return services (Redondi, 2013).

\section{Opportunities and potential problems of TDRs ${ }^{7}$}

Governments can use TDRs to regulate access of certain types of traffic to certain airports serving the same conurbation and not to others. Traffic distribution rules between airports can be based on certain traffic thresholds, such as passenger volumes by route, frequencies or traffic segments (for example, passenger versus full-freighter aircraft).

However, the possibilities for determining connectivity outcomes with TDRs are more limited in practice than they appear at first sight. According to EU Regulation 1008/2008, TDRs shall not discriminate according to the nationality or identity of the carrier. Regulation 1008/2008 also states that TDRs shall not discriminate between destinations. In addition, TDRs are static and focused on the status quo, while the market is changing fast. As they override the market, TDRs may lead to suboptimal welfare outcomes. The performance of TDRs in Europe has been poor. Airlines tend to search for loopholes in the TDRs as the Milan case demonstrates. Some TDRs have been opposed by the airlines because of their de jure and/or de facto discriminatory nature. The case study on the quest for Dutch TDRs (discussed below) also shows the inherent difficulties in designing effective TDRs. 


\section{(Bilateral) Air service agreements and air transport liberalisation}

The availability of traffic rights is a necessary condition to the development of direct connectivity in international markets, but also for the opportunities for a hub carrier to develop its position in the connecting market. With respect to international market access, is not only about the points (airports) than can be served by airlines, but also about freedom of capacity setting (e.g. frequencies) and airline designation/freedom of airline entry.

Many studies have demonstrated the benefits of air transport liberalisation/deregulation on passenger growth, connectivity and welfare. Additional competition (or the threat of competition) and the additional connectivity on offer drive down the cost of air travel and stimulate demand (e.g. Burghouwt and De Wit, 2015a; Cristea et al., 2012; ITF, 2015; InterVISTAS, 2015; Maillebiau and Hansen, 1995; Piermartini and Rousova, 2008; Schipper et al., 2002). Some governments are concerned that liberalisation puts pressure on the direct connectivity levels at the country's airports and the viability of the national carriers. Direct connectivity is generally seen as being superior to a same level of indirect connections. In this view, liberalisation may lead to increased direct services to secondary airports, bypassing the own country's primary hub, which in the long run could lead to a deterioration of the primary hub's direct connectivity. But also the increase in "cheap" indirect connections from primary hubs via foreign hubs may have a negative impact on the profitability of overlapping direct travel options offered by the national hub carrier (for a discussion see ITF, 2015).

\section{Efficient slot allocation}

When airport capacity is constrained but air traffic demand continues to grow, governments may want to ensure that airport capacity at slot-coordinated airports is used in the most efficient way possible, i.e. that slots are used by those airlines that attach the highest value to them. Under the current European slot allocation regime, the slot coordinator allocates slots at slot-coordinated airports in a transparent, neutral and non-discriminatory way, taking into account historic precedence ("grandfather rights"), IATA guidelines on slot allocation, market opportunities for new entrants, PSO's and any applicable local rules. It is rather impossible that such a complex setting results in slots being allocated in an economically efficient way (Starkie, 1998).

A market-based approach to allocate slots is likely to deliver a more efficient outcome. The more rigorous way - auctioning or primary trading - entails the one-off suspension of returning all slots to the pool and suspending grandfather rights, new entrant rule etc. Slots are then allocated to the market using some form of auctioning mechanism in which airlines bid for slots (DotEcon, 2001; Gruyer and Lenoir, 2003; NERA, 2004). Alternatively, governments could do away with the slot regime and opt for a "US" approach. Capacity is then allocated on a first-come-first-serve basis with airlines queuing for runway and gate access. Congestion and delays act as the rationing mechanism. In Europe, primary slot auctioning or abandonment of the slot regime is currently out of reach, mostly for political reasons and vested interests.

Secondary slot trading is a less rigorous approach to achieving a more efficient allocation of slots. The historical precedence of the allocated slots is maintained (grandfather rights), but secondary trading of grandfather slots between airlines is allowed for. Carriers may decide to sell slots to other airlines willing to pay the price involved if carriers are confronted with the opportunity costs of the slots (i.e. the revenue foregone by not trading the slot) in comparison with the value derived from operating these slots (De Wit and Burghouwt, 2008). Carriers that pay most for the slots are likely to be the ones that can get the most money out their own operation. ${ }^{8}$ Within the European framework, the exchange of slots with monetary compensation is allowed by the European Commission. ${ }^{9}$ Slot co-ordinators can set up a slot trading portal to ensure a transparent and smooth trading process, as has been done in the UK. ${ }^{10}$ It is 
unclear, based on public sources, to which extent slot trading takes place at European airports, apart from the London airports.

\section{Local rules in the slot allocation procedure ${ }^{11}$}

The slot co-ordinator or members of the slot co-ordination committee at European airports can propose and agree local rules, which the slot co-ordinator has to take into account in the slot allocation process. The member states and the European Commission have to approve the local rules. The local rules must not affect the independent status of the co-ordinator, but must comply with European Community law and aim at improving the efficient use of airport capacity.

For example, the new runway at Frankfurt resulted in the allocation of a considerable number of new slots to incumbent carriers and new entrants. For competing slot requests from "applicants of equal status" the German slot co-ordinated draft locally-specified guidelines. ${ }^{12}$ The aspects taken into account in the slot allocation guideline mirror partly the additional slot allocation criteria in the IATA World Scheduling Guidelines (par. 8.4.1), which mentions that the co-ordinator should give consideration to factors such as the development of the airport's route network, markets (domestic, short-haul and long-haul), competition and requirements of the travelling public. Yet, the German guidelines on route development have been further specified in relation to the hub function of Frankfurt Airport, amongst other things. For example, it states that the slot co-ordinator bases the allocation of slots in case of competing slot requests on the following criterion: "Best possible utilisation of scarce resources by daily services in comparison to non-daily services, type and availability of the aircraft, additional routes offered by the new inclusion of a region or country, optimal mixture of long-haul, medium-haul and short-haul routes to preserve or improve the hub function".

The Frankfurt example shows that local guidelines may be used to influence connectivity at the margin. Primary slot allocation criteria still hold for the initial slot allocation (grandfather rights, use-itor-loose-it rule, new entrant rule), but a local specification of the slot regulation/guidelines can in principle be made to influence certain connectivity outcomes in case of applicants of equal status.

However, the usability for governments of local rules for influencing connectivity outcomes is limited. Firstly, apart from the use for PSOs and use by new entrants, slots cannot be earmarked for a certain use. This means that the carrier can apply for a slot, with a certain intended use, before deciding to use the slot for a different type of service or exchange the slot with another airline. In other words, the use to which a slot is put and even the airline by which the slot is held can and often does change later. Such changes are determined by the slot holder, not the co-ordinator or the government. Any local rules would only apply to the allocation of newly allocated slots, not to existing slot use. Existing slots subject to historical precedence cannot be forcibly removed from carriers to make them available for other use. Secondly, governments will depend on initiatives from the co-ordination committees or slot coordinators for formulation and implementation.

\section{An administrative or market-based approach?}

In the densely populated urban areas of Western Europe, expanding airport capacity is not easy and - if possible at all - frequently a very lengthy process (ITF, 2014). Governments are often faced with constrained airport capacity for longer periods of time. A common challenge for governments is how to 
make sure that scarce airport capacity is used most efficiently and how to and how to optimise connectivity outcomes given scarce capacity.

\section{The administrative answer}

One of the answers to this challenge is an administrative approach. In essence, this means government intervention through rules and regulations to achieve/determine desired connectivity outcomes in line with their aviation strategy.

We see in practice that an interventionist approach includes the following instruments:

- Traffic distribution rules to achieve a desired traffic distribution between airports serving a certain metropolitan area (see the Milan case study).

- Co-ordinated tariff strategy between airports under common ownership that service a certain metropolitan area. Also here, the objective is to stimulate a certain type of differentiation in connectivity/traffic at the various airports. For example, airport operator SAVE tried to achieve a certain traffic distribution between Treviso and Venice airport by means of charges differentiation and marketing agreements with carriers (Redondi 2012). Also for the future "twin-airport" strategy for Amsterdam Airport and Lelystad Airport, such a co-ordinated tariff strategy is foreseen, complemented with airline marketing incentives and airport facilities dedicated to a certain type of airlines (e.g. low-cost carriers).

- Public service obligations to ensure service from major (congested) airports to peripheral regions. As PSO's are compatible with the European slot allocation regulation, slots can be earmarked for PSO services.

- Local guidelines/rules in the local slot allocation procedure: certain guidelines applied by the slot co-ordinator to give preference to one slot request over another in case of applicants of equal status.

- Bilateral air service agreements can be used to restrict the development of certain airports and concentrate traffic growth at others.

\section{The market-based approach}

The other avenue to achieve a connectivity outcome that reflects society's needs, is for governments to establish the conditions under which the market itself does its work and under which the market can result in efficient connectivity outcome given scarce airport capacity. It is clear that the current European slot allocation regime does not guarantee the most efficient use of airport capacity at constrained airports. Slots are not automatically used by those airlines that value them most, as the primary allocation of slots is not a market-based mechanism and there are no opportunity costs involved for the airlines (other than those of running the flights that use the slot). Airlines hold on to slots as their real market value is not "felt". The other way around, new and incumbent airlines may be unable to acquire the slots they require, even if they can use those slots more efficiently than the carriers using their grandfather rights. 


\section{Box 5. The difficult quest for effective selectivity measures in the Netherlands}

In the Netherlands, the government has made a prioritisation of connectivity outcomes for Amsterdam Airport Schiphol. In a collaborative decision-making process called The Alders Table, former Minister Hans Alders has agreed with the main stakeholders (airline, airport, government authorities, local residents, ATC) that Amsterdam Schiphol (AMS) would be capped at a maximum of 500000 air traffic movements until the year 2020. As the initially forecasted demand was higher than 500000 movements, the regional airports of Eindhoven (EIN) and Lelystad (LEY) were given additional room to grow to accommodate overflow demand. For this purpose, Lelystad Airport would be converted into an airport for large commercial traffic (now general aviation only). The "Alders advice" has been taken over by the Dutch government in their aviation policy.

In addition, it was agreed that, given the scarce (environmental) capacity, newly allocated slots at Amsterdam Schiphol should be used by the traffic contributing most to the network and the Dutch economy ("mainport relatedness"). Lelystad and Eindhoven should accommodate the traffic less relevant to the network/Dutch economy (e.g. leisure traffic). The hub carrier is considered to be crucial for the connectivity of the Netherlands. Without the hub carrier, international connectivity would be much smaller.

The government policy of "selective development of Schiphol's connectivity" has been detailed in a prioritisation of traffic/connectivity segments:

- $\quad$ hub operation (pax and freight) of KLM, SkyTeam and codeshare partners

- traffic of non-hub carriers at intercontinental destinations with more than 10000 outbound business pax per annum (all airlines)

- traffic of non-hub carriers at European destinations with more than 10000 outbound business pax per annum (all airlines)

- $\quad$ non-hub full-freighter traffic

- traffic of non-hub carriers at European or intercontinental destinations with less than 10000 outbound business pax per annum.

The prioritisation has not yet been enforced TDRs (at the time of writing). After various analyses, the Dutch government/Alders Table concluded that TDRs would be difficult to implement if they were to be effective in achieving selective use of Amsterdam Schiphol (risk of discrimination of certain airlines, difficulties of practical implementation). The objective is to let segment 5 (short haul non-business traffic/leisure) use the new Lelystad Airport as much as possible, whereas capacity at Schiphol would be reserved for segment 1-4 (including hub carrier and other business traffic).

Hence, for the time being the strategy is to give airlines incentives to use/not use Amsterdam Schiphol (the "stimulation policy") and use/not use the new Lelystad Airport. The strategy has been laid down in a covenant with the airport operator. The airport operator Schiphol Group (owner and operator of both Amsterdam Schiphol and Lelystad) included the "push and pull" strategy in its business case for Lelystad Airport. Push and pull measures include differentiation in facilities, differentiation in airport charges and marketing incentives. The government may still develop traffic distribution rules as "a last resort" if non-mainport related traffic does not want to move to Lelystad Airport.

At the time of writing, Amsterdam Airport is expected to reach the capacity limit of 500000 movements in 2017. Slot applications are already being declined by the slot co-ordinator. However, the opening of Lelystad Airport for commercial traffic has been delayed until 2019 due to problems of integrating the airport into the ATC system. In the first years of activity, the allowed number of flights at Lelystad Airport will be limited.

To sum up, the Dutch selectivity policy to optimise the connectivity of Amsterdam Airport seemed promising on paper. However, implementation resulted to be much more difficult: designing non-discriminatory but effective traffic distribution rules is practically and legally challenging. 
Within the current European context, a more efficient use of scarce airport capacity can be achieved by ensuring a well-functioning secondary market for trading slots once slots have been allocated in the primary process. ${ }^{13}$ Carriers may decide to sell slots to other airlines willing to pay the price involved if carriers are confronted with the opportunity costs of the slots (i.e. the revenue foregone by not trading the slot) in comparison with the value derived from operating these slots (De Wit and Burghouwt, 2008). Carriers that pay most for the slots are likely to be the ones that can get most money out of their own operation. Slots used for flights that are economically most efficient will eventually "crowd out" flights that are economically less efficient. In case of hub airports, it is probably the hub carrier that is among the airlines with highest willingness to pay (De Wit and Burghouwt, 2008; Mott MacDonald, 2006). A well-functioning and transparent secondary slot market can be achieved by setting up a slot trading portal, like ACL has done for the UK. ${ }^{14}$

Furthermore, it may be important to offer alternatives to airlines at other airports from which they can serve the same market. This will increase the likelihood of airlines selling their slots at the constrained airport and move their operations to other airports in the catchment area. A liquid secondary market helps the operation of an airport system, as it makes it easier for airlines to switch between airports (NERA, 2004, p. 133). The other way around, a multi-airport system helps to maintain (part of the) connectivity to regional or charter destinations as secondary trading may force these services out of the congested airport. In that case, consumers continue to have access to the same wide range of air transport services in the region, but different operations are provided at the various airports according to the willingness to pay of the operators and the congestion levels at the different airports. This is in fact the situation in London: high-capacity flights to long-haul and European business destinations take place at Heathrow, business traffic at London City Airport, while leisure destinations and low-cost flights are mainly served from the other London airports.

Competition forces which can help achieve an economically efficient connectivity outcome in a multi-airport system may be further stimulated when airports have different owners and can therefore provide genuine airport competition. ${ }^{15}$ This means that secondary airport operators with their own business propositions and facilities will need to work hard to attract new traffic, using marketing incentives, possibly lower charges, airline-airport contracts (if possible) and tailor-made facilities/services levels for the targeted airline customers (Starkie, 2012). Instead of governments regulating a certain "optimal" traffic distribution, the market itself generates a traffic distribution and connectivity outcome that is economically efficient, facilitated by secondary slot trading, alternative airport capacity and airport competition.

\section{Intervening to promote connectivity or let the market do its work?}

It may indeed be tempting for governments to intervene in the market with administrative instruments in order to achieve desired connectivity outcomes. It gives a sense of certainty and clarity about the policy outcomes for politicians, but also for other stakeholders such as local communities or industry stakeholders. Outcomes from a market-based approach are much less predictable/certain and will be more difficult to "sell".

We argue that a preferred approach is one that creates the optimal conditions for the market to do its work in case of capacity constraints. In our view, a number of arguments require governments to be cautious about direct intervention through rules and regulations to try and determine connectivity outcomes:

- Lagging behind market dynamics: the air transport industry is very dynamic. Airlines and passengers are increasingly "footloose" (Bush and Starkie, 2014). Airline business models are constantly evolving. Direct government intervention is based on the current status quo. The risk is that government interventions lags behind industry dynamics and will not result in the 
desired change, if there is any impact at all. Regulations such as TDRs are intended to change today's situation, not tomorrow's. It is important to leave maximum room for future developments. Direct government intervention may hinder airline innovation (e.g. in terms of business model development), negatively affecting society's welfare.

- History shows direct government intervention to influence connectivity outcomes is not very successful: history has shown (see e.g. the Milan case, but also the impact of regulation of traffic distribution at Haneda and Narita ${ }^{16}$ ) that the market will work its way around direct government intervention in the market. Airlines search for loopholes in the regulations or just move their capacity elsewhere. Instead of solving market failure, government intervention is likely to replace existing market imperfections by new imperfect regulations.

- Incomplete information: policy makers have incomplete information about industry market dynamics. It is difficult for governments or slot co-ordinators to determine which connections add most value to society (DotEcon, 2011) or how airlines will react to market interventions.

- Industry lobby: design of government regulations that try to directly influence connectivity outcomes is prone to strong industry lobby. Governments may end up with regulations that de facto favor certain carriers or airports.

- Risk of discrimination and court cases: historical cases (Paris, Milan) show that it is often difficult to design traffic distribution rules that are on the one hand effective in achieving desired objective and on the other hand de jure and de facto non-discriminatory towards the nationality or identity of the airline.

To sum up, we argue that there are limits to direct government intervention to influence connectivity outcomes, by imposing for example TDRs. We argue that a policy that creates the conditions for a well-functioning market through secondary slot trading which attaches a price to slots, availability of (alternative) airport capacity and fostering airport competition is likely to be the most fruitful avenue. Such a policy may help to create the conditions in which market forces can help achieve a relatively more efficient connectivity outcome.

Use of administrative instruments may be warranted to achieve certain social objectives. For example, guaranteeing connectivity to and from peripheral regions is many countries an important part of a policy to support residence in remote regions of the country. In addition, an administrative approach may respond to a country's political goals, that do necessarily reflect economic efficiency. One could think about the UK governments' objective to better link Heathrow to the rest of the UK.

\section{Conclusions}

Enhancing air connectivity performance is currently of interest to many governments around the world. This is in particular because of the positive economic externalities associated with connectivity growth, but also fostering connectivity given scarce airport capacity, social objectives and environmental externalities are motives for governments to influence air connectivity outcomes. 
In this paper, we identified a number of instruments that potentially can be part of a government's toolkit to influence connectivity outcomes:

- investments in landside accessibility

- $\quad$ ensuring availability of airport and airspace capacity

- influencing the type of infrastructure available to airlines

- economic regulation of airport charges

- $\quad$ adjusting government fees and taxes

- establishment of a transparent secondary slot market/allowing for secondary slot trading

- negotiation of traffic rights/ air transport liberalisation

- imposing public service obligations

- local rules

- $\quad$ traffic distribution rules.

When reflecting on the different instruments available, we argue that policy makers should be modest about directly influencing connectivity outcomes using an administrative approach. Government interventions that try to regulate certain connectivity outcomes bear the risk of creating government failure and economic inefficiencies. A possible exception are air services under PSO, intended to ensure essential connectivity to peripheral regions.

A more fruitful avenue is likely to be a policy that creates the conditions for airlines to develop their networks. Such a policy relates to ensuring market access for airlines, a transparent, well-functioning secondary slot market, a timely availability of airport (and airspace) capacity and economic regulation of airports in case of substantial market power. Any public investments in airport capacity and landside accessibility should preferably be subject to a careful consideration of costs and benefits.

In this context, the following quote from Harry Bush - former UK CAA regulator - during an Airneth seminar on the public interest of aviation connectivity back in 2014, very well summarises our point: "It is legitimate for policymakers, concerned to improve the economic potential of the country or region they serve, to take an interest in the degree of connectivity offered by airports, whether individually or as a group. However, there is an important difference between taking an interest and taking action, and, if action is to be taken, between interventions that cut across or second-guess the market and those more likely to help it reach an efficient solution". 


\section{References}

Abed, S.Y., A.O. Ba-Fail and S.M. Jasimuddin (2001), "An econometric analysis of international air travel demand in Saudi Arabia". Journal of Air Transport Management, Vol. 7, pp. 143-148.

ACI EUROPE (2016), Airport industry connectivity report.

Airports Commission (2015), Economy: Wider economic impacts assessment. July 2015.

Bhadra, D. (2003), "Demand for Air Travel in the United States: Bottom-up econometric estimation and implications for forecasts by origin and destination pairs". Journal of Air Transportation, Vol. 8/2, pp. 19-56.

Baruffaldi, S.H. (2015), Three essays on the role of proximity in science and innovation (Doctoral dissertation, École Polytechnique Fédérale de Lausanne).

Bel, G. and X. Fageda (2008), "Getting there fast: globalization, intercontinental flights and location of headquarters". Journal of Economic Geography, Vol. 8/4, pp. 471-495.

Bilotkach, V. (2015), "Are airports engines of economic development? A dynamic panel data approach". Urban Studies, Vol. 52/9, pp. 1577-1593.

Brueckner, J.K. (2003), “Airline Traffic and Urban Economic Development. Urban Studies”, Vol. 40/8, pp. $1455-1469$.

Burghouwt, G. and R. Redondi (2013), "Connectivity in air transport networks: an assessment of models and applications". Journal of Transport Economics and Policy, Vol. 47/1, pp. 35-53.

Burghouwt, G. and J.G. de Wit (2015a), "In the wake of liberalisation: long-term developments in the EU air transport market". Transport Policy, Vol. 43, pp. 104-113.

Burghouwt, G. and W. de Wit (2015b), On the mechanisms that can potentially influence connectivity outcomes in the UK. Report commissioned by ITF for the UK Airports Commission. SEO reportnr. 2015-40.

Burghouwt, G. (2016), "Focus on Benefits: Assessing consumer welfare impacts of aviation policy measures". International Transport Forum Discussion Papers, OECD Publishing, Paris. https://www.itf-oecd.org/sites/default/files/docs/asssessing-consumer-welfare-impacts-aviationpolicy.pdf

Bush, H. and D. Starkie (2014), "Competitive drivers towards improved airport/airline relationships". Journal of Air Transport Management, Vol. 41, pp. 45-49.

Copenhagen Economics (2012), Airport competition in Europe. Report commissioned by ACI EUROPE.

Cristea, A., D. Hummels and B. Roberson (2012), Estimating the gains from liberalizing services trade: The case of passenger aviation. University of Oregon, unpublished manuscript.

Dobruszkes, F., M. Lennert and G. Van Hamme (2011), "An analysis of the determinants of air traffic volume for European metropolitan areas". Journal of Transport Geography, Vol. 19/4/, pp. 755762.

DotEcon (2001), Auctioning airport slots. A report for HM Treasury and the Department of the Environment, Transport and the Regions. January 2001.

Eurocontrol (2013), Challenges of Growth 2013. Task 4: European Air Traffic in 2035. STATFOR, June. 
Gillen, D., S. Landau and G.D. Gosling (2015), "Measuring the Relationship Between Airline Network Connectivity and Productivity". Transportation Research Record: Journal of the Transportation Research Board, Vol. 2501, pp. 66-75.

Grosche, T., F. Rothlauf and A. Heinzl (2007), "Gravity models for airline passenger volume estimation". Journal of Air Transport Management, Vol. 13/4, pp. 175-183.

Grubesic, T.H. and F. Wei (2012), "Evaluating the efficiency of the Essential Air Service program in the United States". Transportation Research Part A: Policy and Practice, Vol. 46/10, pp. 1562-1573.

Hovhannisyan, N. and W. Keller (2015), "International business travel: an engine of innovation?" Journal of Economic Growth, Vol. 20/1, pp. 75-104.

IATA (2013), Airport competition. IATA Economics Briefing No. 11.

IATA (2007), Aviation Economic Benefits. Report prepared by InterVISTAS Consulting Inc.

InterVISTAS (2015), The economic impacts of air service liberalization. 11 June.

ITF (2015), Liberalisation of air transport. Summary: policy insights and recommendations. OECD Publishing, Paris. https://www.itf-oecd.org/liberalisation-air-transport-summary-policy-insightsand-recommendations.

ITF (2014), Expanding airport capacity in large urban areas. OECD Publishing, Paris. http://dx.doi.org/10.1787/9789282107393-en

Levine, M. (2009), Airline consolidation: how will it reshape the industry. What does it mean for Europe? First Airneth Annual Lecture, 11 March.

Lieshout, R. (2012), "Measuring the size of an airport's catchment area". Journal of Transport Geography, Vol. 25, pp. 27-34.

Lieshout, R. and H. Matsumoto (2012), "New international services and the competitiveness of Tokyo International Airport". Journal of Transport Geography, Vol. 22, pp. 53-64.

Lieshout, R., G. Burghouwt and T. Boonekamp (2015), Economic value of the hub function of Schiphol (in Dutch). SEO reportnr. 2015-22. http://www.seo.nl/uploads/media/201522_Economisch_belang_van_de_hubfunctie_van_Schiphol.pdf

Lieshout, R., P. Malighetti, R. Redondi and G. Burghouwt (2016), "The competitive landscape of air transport in Europe". Journal of Transport Geography, Vol. 50, pp. 68-82.

Maillebiau, E. and M. Hansen (1995), "Demand and consumer welfare impacts of international airline liberalisation: the case of the North Atlantic". Journal of Transport Economics and Policy, pp. 115-136.

Mandel, B., M. Gaudry and D. Ungemach (2017), Europe-wide aviation connectivity measures and the PATH theorem. Working paper.

Mott MacDonald (2006), Study on the impact of the introduction of secondary trading at community airports. Volume 1,. November.

NERA (2004), Study to assess the effects of different slot allocation schemes. A final report for the European Commission, DG Tren.

Oum, T. and X. Fu (2008), "Impacts of airports on airline competition: focus on airport performance and airport-airline vertical relations". OECD/ITF Joint Transport Research Centre Discussion Papers, No. 2008/17, OECD Publishing, Paris. http://dx.doi.org/10.1787/235140743836 
Piermartini, R. and L. Rousova (2008). "Liberalization of air transport services and passenger traffic". WTO Staff Working Paper ERSD-2008-06.

Redondi, R., P. Malighetti and S. Paleari (2012), "De-hubbing of airports and their recovery patterns". Journal of Air Transport Management, Vol. 18/1, pp. 1-4.

Redondi, R. (2013), "Traffic distribution rules in the Milan airport system: effects and policy implications". Journal of Transport Economics and Policy, Vol. 47/3, pp. 493-499.

Schipper, Y. (2002), "Market structure and environmental costs: An analysis of air transport liberalization". International Journal of Transport Economics, pp. 17-41.

Starkie, D. (2012), European airports and airlines: Evolving relationships and the regulatory implications. Journal of Air Transport Management, 21, 40-49.

Starkie, D. (1998), "Allocating airport slots: A role for the market?" Journal of Air Transport Management, Vol. 4/2, pp. 111-116.

van Spijker, V., J. Zuidberg and T. Boonekamp (2017), Monitor network quality and state assurances 2009-2016 (in Dutch). SEO reportnr. 2016-105. http://www.seo.nl/uploads/media/2016105_Monitor_Netwerkkwaliteit_en_Staatsgaranties.pdf

de Wit, J.G. and G. Burghouwt (2008), "Slot allocation and use at hub airports, perspectives for secondary trading". European Journal of Transport and Infrastructure Research, Vol. 8/2, pp. 147-164.

Zuidberg, J. (2014), "Key drivers for differentiated airport passenger service charges". Journal of Transport Economics and Policy, Vol. 48/2, pp. 279-295.

\section{Notes}

\footnotetext{
Some sort of congestion/peak-load pricing of facilities can be a remedy for achieving a more efficient utilisation of congested airport capacity. However, congestion pricing is difficult to achieve due to vested interests (Oum and Fu, 2008) and may run against international agreements.

Guidelines on state aid to airports and airlines. C(2014) 963. See for details the communication from the Commission - Guidelines on State aid to airports and airlines, http://eur-lex.europa.eu/legalcontent/EN/TXT/PDF/?uri=OJ:C:2014:099:FULL\&from=EN

This section is based on Burghouwt and de Wit (2015b) unless otherwise stated.

See for example Grubesic and Wei (2012).

This section is based on Burghouwt and de Wit (2015b) unless otherwise stated. http://www.slottrade.aero/library/London\%20Traffic\%20Distribution\%20Rules\%201991.pdf;

https://www.caa.co.uk/Commercial-industry/Airports/Economic-regulation/Licensing-and-price-control/Airporteconomic-licensing-and-price-control/

This section is based on Burghouwt and de Wit (2015b).

However, airlines may decide to strategise to prevent others from market entry. There is also the question of having sufficient up-front resources to outbid the big players.

In the sense that the EC stated in its communication of April 2008 that "given that there is no clear and explicit prohibition of such exchanges, the Commission does not intend to pursue infringement proceedings against Member States where such exchanges take place in a transparent manner, respecting all the other administrative requirements for the allocation of slots set out in the applicable legislation" (COM 2008 (227).
} 
10 See http://www.slottrade.aero/

This section is based on Burghouwt and De Wit (2015b).

Guideline for the allocation of scarce slots at coordinated German Airports

We consider primary trading/auctioning of slots and congestion pricing to be mostly out of reach mostly for political reasons, at least in the European context.

http://www.slottrade.aero/how-slottrade-works.asp

According to Bush and Starkie (2014) and Copenhagen Economics (2012), airport competition in Europe increased over the past decade. This conclusion has been opposed by others (IATA 2013)

16 This policy stimulated the use of foreign hub airports by passengers travelling from regional Japanese airports. 
